\section{Comparison of the Solid Phase-supported Receptor and Ligand Competitive Assays for Biotin}

\author{
Makoto Muratsugu, ${ }^{*}$ Namiko Amano, \\ and Rie Takeda
}

Bioanalytical Science Laboratory, Department of Clinical Nutrition, Osaka Prefecture University, 3-7-30 Habikino, Habikino, Osaka 583-8555, Japan

(Received May 22, 2009; Accepted August 18, 2009)

Solid phase-supported receptor and ligand competitive assays for biotin were tested with respect to a mathematical model. We could assume the same mathematical model for both the solid phasesupported receptor and ligand competitive assays. In addition, we could eliminate the so-called blocking procedure in these assays. The amount of immobilizing reagent (biotinylated bovine serum albumin, BBSA) in the solid phase-supported ligand competitive assay was less than that (avidin) in the solid phasesupported receptor competitive assay. Desthiobiotin and biocytin influenced the solid phase-supported ligand competitive assay, but lipoic acid and lysine did not.

Key words — biotin, competitive assay, computer simulation, blocking procedure

\section{INTRODUCTION}

Biotin is a water-soluble vitamin that acts as a prosthetic group in acetyl-CoA carboxylase, pyruvate carboxylase, propionyl-CoA carboxylase, and 3-methyl-crotonyl-CoA carboxylase in humans. ${ }^{1,2)}$ In addition to these enzymes, there are other biotinbinding proteins such as avidin, ${ }^{3)}$ streptavidin, ${ }^{3)}$ bradavidin, ${ }^{4)}$ egg-yolk biotin-binding protein, ${ }^{5)}$ nuclear biotin-binding protein, ${ }^{6}$ ) biotin-biding immunoglobulins, ${ }^{7,8)}$ biotinidase, ${ }^{6}$ ) and biotin protein ligase. ${ }^{9,10)}$

Various microbiological and chemical assays

\footnotetext{
${ }^{*}$ To whom correspondence should be addressed: Bioanalytical Science Laboratory, Department of Clinical Nutrition, Osaka Prefecture University, Habikino, Osaka 583-8555, Japan. Tel.: +81-729-50-2111 (Ext. 3132); Fax: +81-729-50-2127; E-mail: mmakoto@rehab.osakafu-u.ac.jp
}

for biotin have been developed. Several of the many microorganisms requiring biotin as a growth factor have been used in assays for biotin. A turbidimetric method using Lactobacillus plantarum (formerly called L.arabinosus) has been widely used, ${ }^{11)}$ and a more precise agar plate method 12) using L.plantarum was also recently developed. Binding assays using avidin or streptavidin are classified into two groups: those where biotin competes with radioisotope- or enzyme-labeled biotin for immobilized avidin or streptavidin and those where biotin competes with immobilized biotin for enzyme- or radioisotope-labeled avidin or streptavidin. The former type of assay is called a solid phase-supported receptor competitive assay (Fig. 1a) and the latter a solid phase-supported ligand competitive assay (Fig. 1b). In the solid phase-supported receptor assay, biotin and enzymelabeled biotin are added almost simultaneously to the avidin-immobilized solid phase, and unbound biotin and labeled biotin are removed. In the solid phase-supported ligand assay, free biotin is first added to the biotin-immobilized solid phase, then the enzyme-labeled streptavidin is immediately added, and the biotin-bound enzyme-labeled streptavidin is finally removed.

In this study, we investigated a mathematical model of the solid phase-supported receptor competitive assay and the solid phase-supported ligand competitive assay. The same model could be used for both assays. In addition, we showed that the so-called blocking procedure could be eliminated in both solid phase-supported receptor and ligand competitive assays, but that the latter assay was better than the former for practical use.

Simulation Study - Biotin binds strongly to avidin or streptavidin, which both have four binding sites. We assumed that each biotin molecule (ligand) bound to an avidin or streptavidin molecule (receptor) in order to simplify the model in this study.

The reaction of the solid phase-supported receptor competitive assay is schematized in the following reaction schemes:

$$
\begin{aligned}
& \mathrm{P}_{\mathrm{R}}+\mathrm{Q}_{\mathrm{R}} \rightleftharpoons \mathrm{P}_{\mathrm{R}}+\mathrm{Q}_{\mathrm{R}} \\
& \mathrm{P}_{\mathrm{R}}^{*}+\mathrm{Q}_{\mathrm{R}} \rightleftharpoons \mathrm{P}_{\mathrm{R}}^{*} \mathrm{Q}_{\mathrm{R}},
\end{aligned}
$$

where $\mathrm{P}_{\mathrm{R}}, \mathrm{P}_{\mathrm{R}}^{*}$, and $\mathrm{Q}_{\mathrm{R}}$ represent ligand, enzymelabeled ligand, and solid phase-supported receptor, respectively. The equilibrium constants for these reactions, schemes (R1) and (R2), are designated as $K_{\mathrm{R}}$ and $K_{\mathrm{R}}^{*}$, respectively: 


$$
\begin{gathered}
K_{\mathrm{R}}=\frac{\left[\mathrm{P}_{\mathrm{R}} \mathrm{Q}_{\mathrm{R}}\right]}{\left[\mathrm{P}_{\mathrm{R}}\right]\left[\mathrm{Q}_{\mathrm{R}}\right]} \\
K_{\mathrm{R}}^{*}=\frac{\left[\mathrm{P}_{\mathrm{R}}^{*} \mathrm{Q}_{\mathrm{R}}\right]}{\left[\mathrm{P}_{\mathrm{R}}^{*}\right]\left[\mathrm{Q}_{\mathrm{R}}\right]},
\end{gathered}
$$

The total concentrations of ligand $\left(p_{\mathrm{R}}\right)$, enzymelabeled ligand $\left(p_{\mathrm{R}}^{*}\right)$, and solid phase-supported re- ceptor $\left(q_{\mathrm{R}}\right)$ are given by

$$
\begin{aligned}
& p_{\mathrm{R}}=\left[\mathrm{P}_{\mathrm{R}}\right]+\left[\mathrm{P}_{\mathrm{R}} \mathrm{Q}_{\mathrm{R}}\right] \\
& p_{\mathrm{R}}^{*}=\left[\mathrm{P}_{\mathrm{R}}^{*}\right]+\left[\mathrm{P}_{\mathrm{R}}^{*} \mathrm{Q}_{\mathrm{R}}\right] \\
& q_{\mathrm{R}}=\left[\mathrm{Q}_{\mathrm{R}}\right]+\left[\mathrm{P}_{\mathrm{R}} \mathrm{Q}_{\mathrm{R}}\right]+\left[\mathrm{P}_{\mathrm{R}}^{*} \mathrm{Q}_{\mathrm{R}}\right],
\end{aligned}
$$

Assuming $K_{\mathrm{R}}^{*}=K_{\mathrm{R}}$, the following equation is derived from Eq. (R3) to Eq. (R7):

$$
\left[\mathrm{P}_{\mathrm{R}}^{*} \mathrm{Q}_{\mathrm{R}}\right]=\frac{p_{\mathrm{R}}^{*}\left[\left[K_{\mathrm{R}}\left(p_{\mathrm{R}}+p_{\mathrm{R}}^{*}\right)+K_{\mathrm{R}} q_{\mathrm{R}}+1\right] \pm \sqrt{K_{\mathrm{R}}^{2}\left(p_{\mathrm{R}}+p_{\mathrm{R}}^{*}\right)^{2}+2 K_{\mathrm{R}}\left(1-K_{\mathrm{R}} q_{\mathrm{R}}\right)\left(p_{\mathrm{R}}+p_{\mathrm{R}}^{*}\right)+\left(K_{\mathrm{R}} q_{\mathrm{R}}+1\right)^{2}}\right]}{2 K_{\mathrm{R}}\left(p_{\mathrm{R}}+p_{\mathrm{R}}^{*}\right)}
$$

The reaction of the solid phase-supported ligand competitive assay is schematized in the following reaction schemes:

$$
\begin{aligned}
& \mathrm{P}_{\mathrm{L} f}+\mathrm{Q}_{\mathrm{L}}^{*} \rightleftharpoons \mathrm{P}_{\mathrm{L} f} \mathrm{Q}_{\mathrm{L}}^{*} \\
& \mathrm{P}_{\mathrm{L} s}+\mathrm{Q}_{\mathrm{L}} \rightleftharpoons \mathrm{P}_{\mathrm{L} s} \mathrm{Q}_{\mathrm{L}}^{*},
\end{aligned}
$$

where $\mathrm{P}_{\mathrm{L} f}, \mathrm{P}_{\mathrm{L} s}$, and $\mathrm{Q}_{\mathrm{L}}^{*}$ represent free ligand, solid phase-supported ligand, and enzyme-labeled receptor, respectively. The equilibrium constants for these reactions, schemes (L1) and (L2), are designated as $K_{\mathrm{L} f}$ and $K_{\mathrm{Ls}}$, respectively:

$$
K_{\mathrm{L} f}=\frac{\left[\mathrm{P}_{\mathrm{L} f} \mathrm{Q}_{\mathrm{L}}^{*}\right]}{\left[\mathrm{P}_{\mathrm{L} f}\right]\left[\mathrm{Q}_{\mathrm{L}}^{*}\right]}
$$

(a)

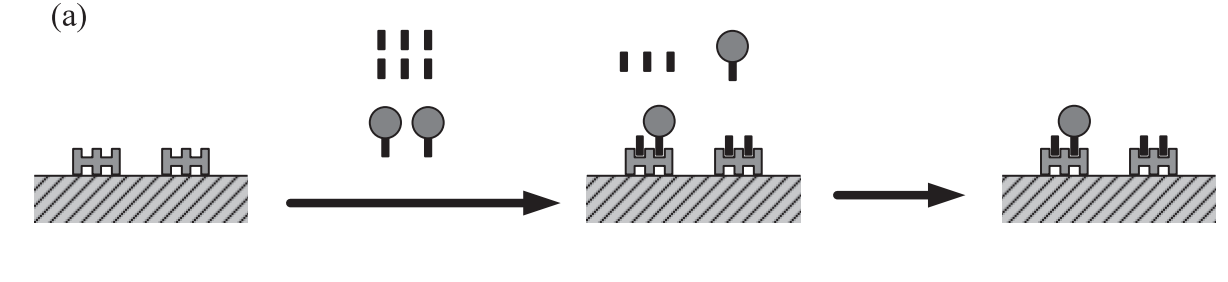

(b)

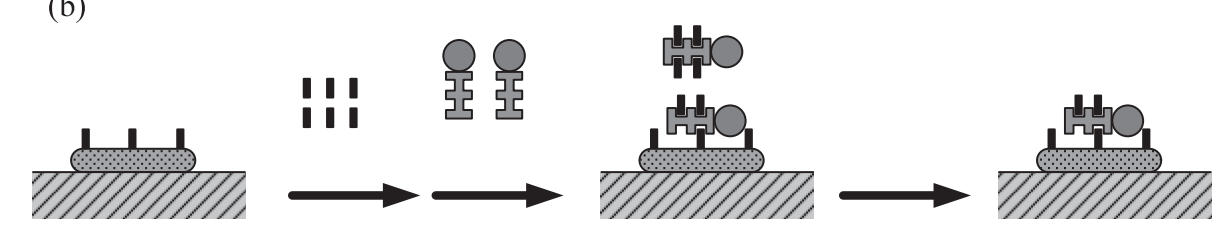

Solid phase-supported receptor (avidin)

$$
\begin{aligned}
& \text { Enzyme-labeled } \\
& \text { ligand (biotin) }
\end{aligned}
$$

Ligand (biotin)
Solid phase-supported ligand (biotin)

Enzyme-labeled receptor (streptavidin)

Fig. 1. Concept of the Solid Phase-supported Receptor Competitive Assay (a) and the Solid Phase-supported Ligand Competitive Assay (b). 


$$
K_{\mathrm{L} s}=\frac{\left[\mathrm{P}_{\mathrm{Ls}} \mathrm{Q}_{\mathrm{L}}^{*}\right]}{\left[\mathrm{P}_{\mathrm{L} s}\right]\left[\mathrm{Q}_{\mathrm{L}}^{*}\right]},
$$

The total concentrations of free ligand $\left(p_{\mathrm{L} f}\right)$, solid phase-supported ligand $\left(p_{\mathrm{L} s}\right)$, and enzyme-labeled receptor $\left(q_{\mathrm{L}}^{*}\right)$ are given by

$$
\begin{aligned}
& p_{\mathrm{L} f}=\left[\mathrm{P}_{\mathrm{L} f}\right]+\left[\mathrm{P}_{\mathrm{L} f} \mathrm{Q}_{\mathrm{L}}^{*}\right] \\
& p_{\mathrm{L} s}=\left[\mathrm{P}_{\mathrm{L} s}\right]+\left[\mathrm{P}_{\mathrm{L} s} \mathrm{Q}_{\mathrm{L}}^{*}\right] \\
& q_{\mathrm{L}}^{*}=\left[\mathrm{Q}_{\mathrm{L}}^{*}\right]+\left[\mathrm{P}_{\mathrm{L}} \mathrm{Q}_{\mathrm{L}}^{*}\right]+\left[\mathrm{P}_{\mathrm{Ls}} \mathrm{Q}_{\mathrm{L}}^{*}\right],
\end{aligned}
$$

Assuming $K_{\mathrm{L} s}=K_{\mathrm{L} f}$, the following equation is derived from Eq. (L3) to Eq. (L7):

$$
\left[\mathrm{P}_{\mathrm{L} s} \mathrm{Q}_{\mathrm{L}}^{*}\right]=\frac{p_{\mathrm{L} s}\left[\left[K_{\mathrm{L} f}\left(p_{\mathrm{L} f}+p_{\mathrm{L} s}\right)+K_{\mathrm{L} f} q_{\mathrm{L}}^{*}+1\right] \pm \sqrt{K_{\mathrm{L} f}^{2}\left(p_{\mathrm{L} f}+p_{\mathrm{L} s}\right)^{2}+2 K_{\mathrm{L} f}\left(1-K_{\mathrm{L} f} q_{\mathrm{L}}^{*}\right)\left(p_{\mathrm{L} f}+p_{\mathrm{L} s}\right)+\left(K_{\mathrm{L} f} q_{\mathrm{L}}^{*}+1\right)^{2}}\right]}{2 K_{\mathrm{L} f}\left(p_{\mathrm{L} f}+p_{\mathrm{L} s}\right)},
$$

Since Eq. (L8) is equivalent to Eq. (R8), we can use the following equation for the simulation of both solid phase-supported ligand and receptor competitive assays:

$$
[\mathrm{PQ}]=\frac{p^{\prime}\left[\left[K\left(p+p^{\prime}\right)+K q+1\right] \pm \sqrt{K^{2}\left(p+p^{\prime}\right)^{2}+2 K(1-K q)\left(p+p^{\prime}\right)+(K q+1)^{2}}\right]}{2 K\left(p+p^{\prime}\right)},
$$

where $p$ represents the concentration of ligand in standards or samples, and the intensity of color after an enzyme reaction is proportional to [PQ]. The computer simulation was performed using Eq. (LR9) in Excel ${ }^{\mathrm{TM}}$ (Microsoft Co., Redmond, WA, U.S.A.).

\section{MATERIALS AND METHODS}

Materials — The following materials were obtained from the sources indicated: flat-bottomed multiwell microplates (96 wells, Summilon H) and ELISA Color Reagent kit (Type O) from Sumitomo Bakelite Co., Ltd., Tokyo, Japan; avidin from Wako Pure Chemical Industries, Ltd., Osaka, Japan; $N$ hydroxysuccinimidobiotin (NHS-biotin) and BCA Protein Assay Reagent kit from Pierce Chemical Co., Rockford, IL, U.S.A.; biotin, horse radish peroxidase (HRP)-streptavidin, bovine serum albumin (BSA), desthiobiotin, biocytin, lipoic acid, and lysine from Sigma Chemical Co., St. Louis, MO, U.S.A.; and HRP-biotin from Vector Laboratories, Inc., Burlingame, CA, U.S.A. All other chemicals were of reagent grade or better. The water used was 17-Mohm grade.
Biotinylation of BSA (B-BSA) — BSA was biotinylated by the method previously reported. ${ }^{13)}$ Briefly, NHS-biotin reacted with the primary amines in the side chains of lysine residues in BSA. The amount of B-BSA was expressed as the amount of BSA, which was determined using the BCA Protein Assay Reagent kit with BSA as the standard for B-BSA.

Solid Phase-supported Receptor Competitive Assay _ Multiwell microplates were coated with avidin in Dulbecco's phosphate buffered saline without $\mathrm{Ca}^{2+}$ or $\mathrm{Mg}^{2+}$ (PBS) containing $0.02 \%$ $\mathrm{NaN}_{3}$ (PBS-N) in each well, then incubated overnight at $4^{\circ} \mathrm{C}$. After the wells were washed three times with PBS-N, $300 \mu$ of $1 \%$ BSA in PBS$\mathrm{N}$ (BSA/PBS-N) was added to each well. The plates were incubated for $2 \mathrm{hr}$ at $37^{\circ} \mathrm{C}$ and washed three times with PBS containing $0.05 \%$ merthiolate (PBS-M). Fifty microliters of test solution was added to each well followed by $50 \mu \mathrm{l}$ of HRP-biotin. The plates were incubated for $1 \mathrm{hr}$ at $37^{\circ} \mathrm{C}$, then washed three times with PBS-M. One hundred microliters of substrate solution in the ELISA Color Reagent kit was added to each well. After the plate was incubated for a fixed time at $25^{\circ} \mathrm{C}$, the color reaction was terminated by the addition of a reaction stop solution in the kit to each well. Ab- 
sorbance at $490 \mathrm{~nm}$ was then measured in a microplate reader (Model 450, Bio-Rad Labs., Richmond, CA, U.S.A.) and the data were transferred to a computer using a custom-made program for data analysis. ${ }^{14)}$

Solid Phase-supported Ligand Competitive Assay — Multiwell microplates were coated with BBSA by adding B-BSA in PBS-N to each well, then incubated overnight at $4^{\circ} \mathrm{C}$. After the wells were washed three times with PBS-N, $300 \mu \mathrm{l}$ of BSA/PBS-N was added to each well. The plates were incubated for $2 \mathrm{hr}$ at $37^{\circ} \mathrm{C}$ and washed three times with PBS-M. Fifty microliters of test solution was added to each well followed by $50 \mu$ of HRP-streptavidin. The plates were incubated for $1 \mathrm{hr}$ at $37^{\circ} \mathrm{C}$, then washed three times with PBS-M. One hundred microliters of substrate solution in the ELISA Color Reagent kit was added to each well. After the plates were incubated for a fixed time at $25^{\circ} \mathrm{C}$, the color reaction was terminated by the addition of a reaction stop solution in the kit to each well. Absorbance at $490 \mathrm{~nm}$ was then measured in the microplate reader and the data were transferred to a computer using a custom-made program for data analysis. ${ }^{14)}$

\section{RESULTS AND DISCUSSION}

\section{Simulation Study}

The [PQ] value can be calculated from Eq. (LR9). Simulated plots of $[\mathrm{PQ}]$ as a function of $p$ are shown in Figs. 2 and 3. $p$ is the total concentration of ligand ([biotin] in standards).

Figure 2 shows that the dose-response curves were affected by $q . q$ is the total concentration of solid phase-supported receptor (avidin) in the solid phase-supported receptor competitive assay and the total concentration of enzyme-labeled receptor (HRP-streptavidin) in the solid phase-supported ligand competitive assay. At lower $q$ values, the doseresponse curve moved leftward. This result indicates that the lower the total concentration of solid phase-supported receptor or enzyme-labeled receptor, the better the range of detection.

Figure 3 shows that the dose-response curves were affected by $p^{\prime} . p^{\prime}$ is the total concentration of enzyme-labeled ligand (HRP-biotin) for the solid phase-supported receptor competitive assay and the total concentration of solid phase-supported ligand (B-BSA) for the solid phase-supported ligand competitive assay. The lower the $p^{\prime}$ value, the lower the

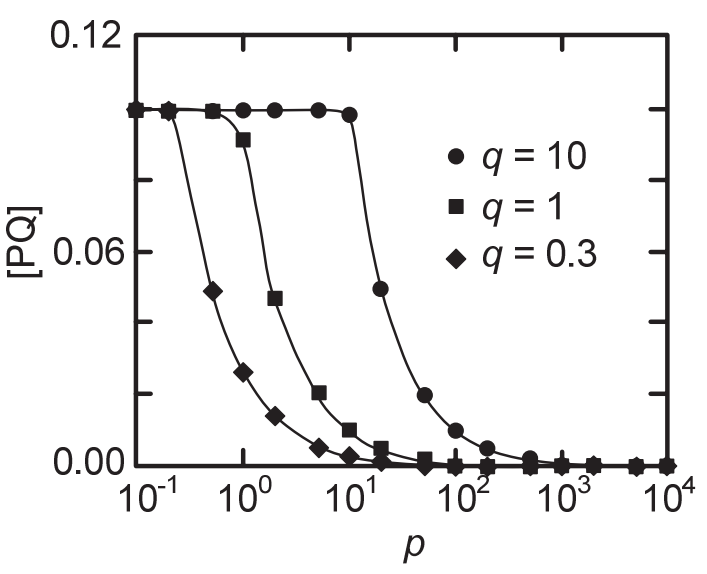

Fig. 2. Dose-response Curves for the Solid Phase-supported Receptor or Ligand Competitive Assay: the Effect of $q$

$K=10^{15}, p^{\prime}=0.1$.

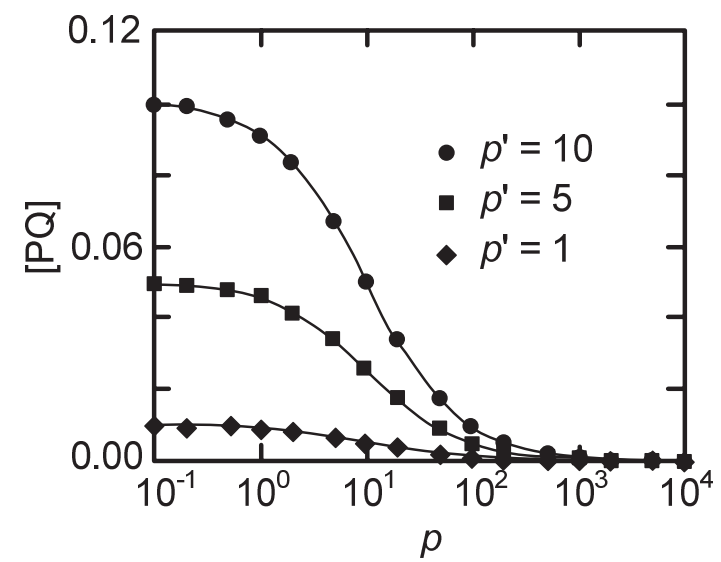

Fig. 3. Dose-response Curves for the Solid Phase-supported Receptor or Ligand Competitive Assay: the Effect of $p^{\prime}$

$K=10^{15}, q=1$.

[PQ] value, indicating that the higher the total concentration of enzyme-labeled ligand or solid phasesupported ligand, the better the range of detection.

\section{Experimental Study}

It is generally difficult to measure the total concentrations of solid phase-supported receptor (avidin) and solid phase-supported ligand (B-BSA) in the solid phase-supported receptor and ligand competitive assays, respectively. However, the total concentration is proportional to the concentration of avidin or B-BSA added to the microplate wells to immobilize avidin or B-BSA. The doseresponse curves for the solid phase-supported receptor competitive assay were obtained (Fig. 4a), for various concentrations of added avidin $(0.050,0.50$, 


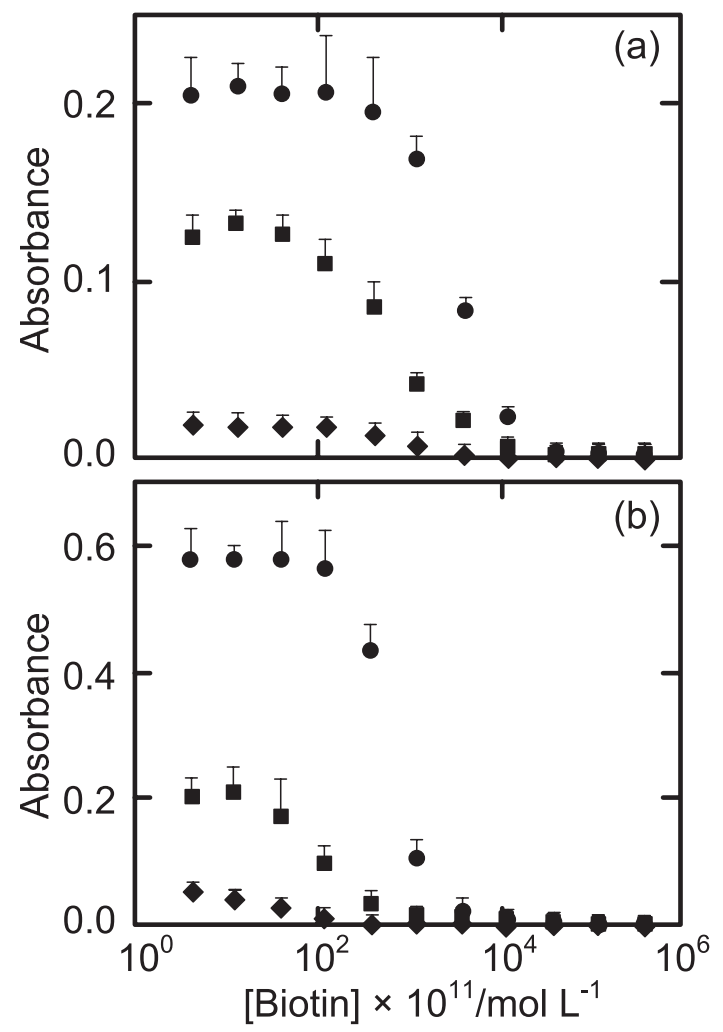

Fig. 4. Dose-response Curves for the Solid Phase-supported Receptor Competitive Assay for Various Concentrations of Avidin (a) and the Solid Phase-supported Ligand Competitive Assay for Various Concentrations of HRP-streptavidin (b)

(a) $\bullet, 0.050 \mu \mathrm{g} \mathrm{ml}^{-1} ; \mathbf{-}, 0.50 \mu \mathrm{g} \mathrm{ml}^{-1} ; \circ, 1.0 \mu \mathrm{g} \mathrm{m}^{-1}$ avidin. $0.50 \mu \mathrm{g} \mathrm{ml} l^{-1}$ HRP-biotin. (b) $\bullet, 0.025 \mu \mathrm{g} \mathrm{ml}^{-1}$; $\mathbf{m}, 0.050 \mu \mathrm{g} \mathrm{ml}^{-1}$; $\bullet, 0.13 \mu \mathrm{g} \mathrm{ml}^{-1} \mathrm{HRP}$-streptavidin. $0.10 \mu \mathrm{g} \mathrm{ml}^{-1} \mathrm{~B}$-BSA. The vertical bars indicate the standard deviation for the mean of duplicate.

$\left.1.0 \mu \mathrm{g} \mathrm{ml}^{-1}\right)$ at a constant concentration of enzymelabeled ligand $\left(0.50 \mu \mathrm{g} \mathrm{ml}^{-1}\right.$ HRP-biotin). The dose-response curves for the solid phase-supported ligand competitive assay were obtained (Fig. 4b) for various concentrations of added HRP-streptavidin $\left(0.025,0.050,0.13 \mu \mathrm{g} \mathrm{ml}^{-1}\right)$ at a constant concentration of solid phase-supported receptor $(0.10 \mu \mathrm{g}$ $\mathrm{ml}^{-1} \mathrm{~B}-\mathrm{BSA}$ ). These experimental results support the validity of the result (Fig. 2) of the simulation study. Note that $q$ in Eq. (LR9) denotes the concentration of avidin in the solid phase-supported receptor competitive assay or HRP-streptavidin in the solid phase-supported ligand competitive assay. When $K$ in Eq. (LR9) was 10, the simulated dose response curves were similar to the dose response curves showed in Fig. 4 (data not shown). Therefore, $K$ of avidin adsorbed to the microplate or HRP-conjugated streptavidin may differ from $K$ (ca. $10^{15}$ ) of native avidin or streptavidin.

The dose-response curves for the solid phase-

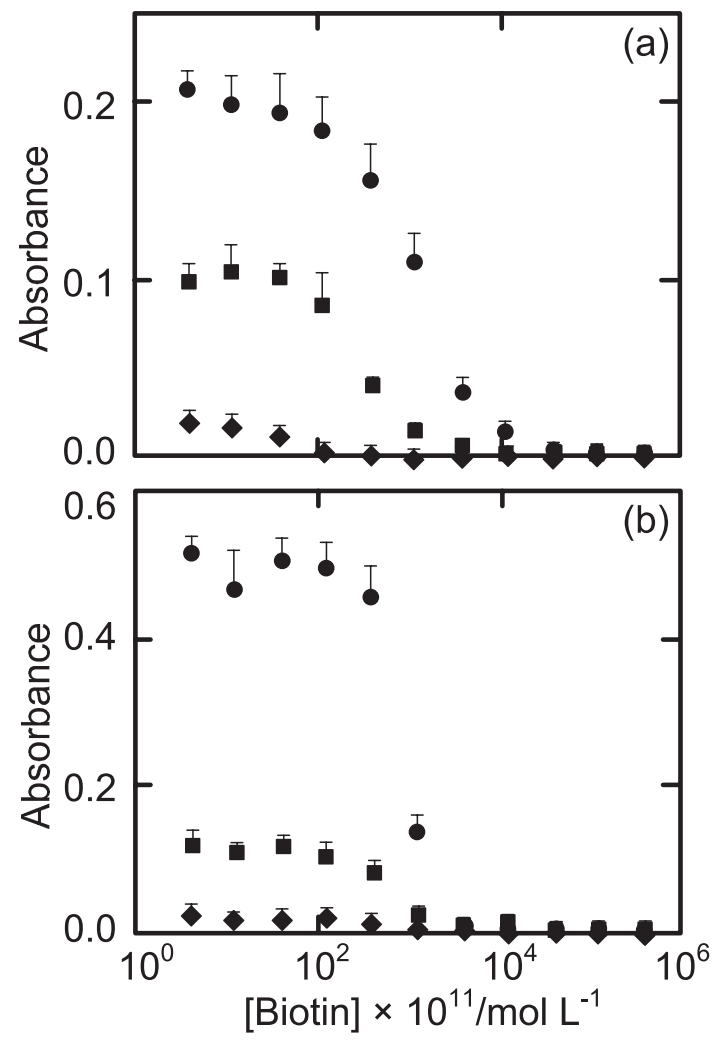

Fig. 5. Dose-response Curves for the Solid Phase-supported Receptor Competitive Assay for Various Concentrations of HRP-biotin (a) and the Solid Phase-supported Ligand Competitive Assay for Various Concentrations of B-BSA (b)

(a) $\bullet, 0.0050 \mu \mathrm{g} \mathrm{ml}^{-1} ; \mathbf{-}, 0.050 \mu \mathrm{g} \mathrm{ml} l^{-1}(n=4) ; \bullet, 0.50 \mu \mathrm{g}$ $\mathrm{ml}^{-1}$ HRP-biotin $(n=4) . \quad 1.0 \mu \mathrm{g} \mathrm{ml}^{-1}$ avidin. (b) $\bullet, 0.0010 \mu \mathrm{g}$ $\mathrm{ml}^{-1} ; \bullet, 0.010 \mu \mathrm{g} \mathrm{ml}^{-1} ; \bullet, 0.10 \mu \mathrm{g} \mathrm{ml}^{-1}$ B-BSA. $0.13 \mu \mathrm{g} \mathrm{ml}^{-1} \mathrm{HRP}-$ streptavidin. The vertical bars indicate the standard deviation for the mean of duplicate or quadruplicate.

supported receptor competitive assay were obtained (Fig. 5a) for various concentrations of enzymelabeled ligand (HRP-biotin; 0.0050, 0.050, $0.50 \mu \mathrm{g}$ $\left.\mathrm{ml}^{-1}\right)$ at a constant concentration of added avidin $\left(1.0 \mu \mathrm{g} \mathrm{ml}^{-1}\right)$. The dose-response curves for the solid phase-supported ligand competitive assay were obtained (Fig. 5b) for various concentrations of solid phase-supported receptor (B-BSA; 0.0010, $\left.0.010,0.10 \mu \mathrm{g} \mathrm{ml}^{-1}\right)$ at a constant concentration of added HRP-streptavidin $\left(0.13 \mu \mathrm{g} \mathrm{ml}^{-1}\right)$. These results support the validity of the result (Fig. 3) of the simulation study. Note that $p^{\prime}$ in Eq. (LR9) denotes the concentration of HRP-biotin in the solid phasesupported receptor competitive assay or B-BSA in the solid phase-supported ligand competitive assay.

Figures 4 and 5 indicate that the same mathematical model can be used for the solid phasesupported receptor and ligand competitive assays. When we use these assays, we must notice that 
the dose-response curves could be affected by the properties of HRP-streptavidin, HRP-biotin, immobilized avidin, immobilized B-BSA, the sensitivity of a microplate reader, etc.

\section{Blocking Procedure}

The blocking procedure in the solid phasesupported receptor competitive assay or the solid phase-supported ligand competitive assay reduced the nonspecific binding of HRP-biotin or HRPstreptavidin, respectively (data not shown). The blocking procedure was essential in these assays, and $1 \%$ BSA was used as a blocking reagent. Two steps (immobilizing and blocking) are generally required in these assays (Procedure A), but we investigated whether we could simplify the blocking process. A solution containing avidin or BBSA in BSA/PBS-N was added to a microplate for the solid phase-supported receptor competitive assay or the solid phase-supported ligand competitive assay, respectively (Procedure B). Figure 6 shows that Procedure B successfully produced dose response curves for these assays, although Procedure $\mathrm{B}$ required about 100 times more immobilizing reagent than Procedure A. In addition, the response curves for Procedure B shifted toward the low biotin concentration region compared with those for Procedure A (Fig. 6). The result indicates that the amount of immobilized avidin in Procedure B might be less than that in Procedure A, consider-

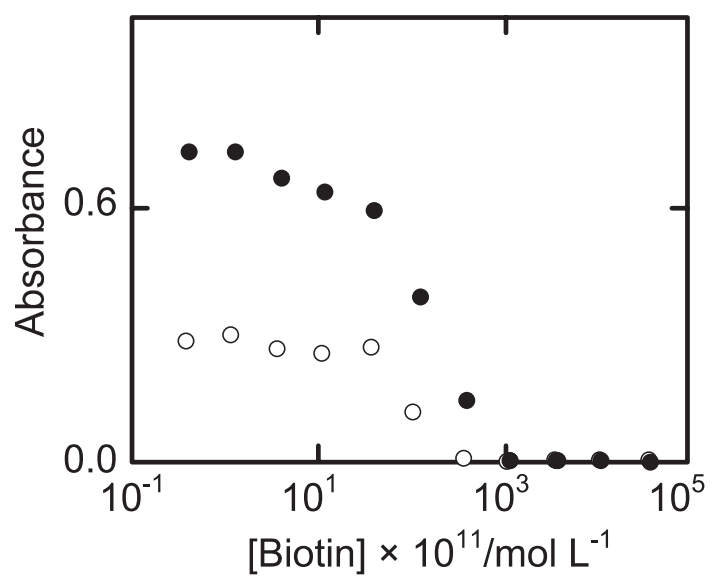

Fig. 6. Dose-response Curves for the Solid Phase-supported Ligand Competitive Assay (•) and the Solid Phasesupported Receptor Competitive Assay $(\bigcirc)$ using a Microplate Immobilized with B-BSA and Avidin in a Blocking Reagent, Respectively

- $10 \mu \mathrm{g} \mathrm{m}{ }^{-1}$ B-BSA in BSA/PBS-N, $0.13 \mu \mathrm{g} \mathrm{ml}{ }^{-1}$ HRPstreptavidin; $\bigcirc, 100 \mu \mathrm{g} \mathrm{ml}^{-1}$ avidin in BSA/PBS-N, $0.50 \mu \mathrm{g} \mathrm{ml}^{-1} \mathrm{HRP}$ biotin. ing the results of the simulation and experimental studies (Figs. 2 and 4a). However, the smaller amount of immobilized B-BSA could not explain the shift of the response curves in the solid phasesupported ligand competitive assay. The immobilizing reagent (avidin or B-BSA) and the blocking reagent ( $1 \% \mathrm{BSA}$ ) were simultaneously added to the microplate, resulting in termination of the blocking procedure. The amount of immobilizing reagent (BBSA) in the solid phase-supported ligand competitive assay was less than that (avidin) in the solid phase-supported receptor competitive assay. In addition, Fig. 6 shows that the dose-response curve for the solid phase-supported ligand (biotin) competitive assay was better than that for the solid phasesupported receptor (avidin).

Influence of Desthiobiotin, Biocytin, Lipoic Acid, and Lysine on the Solid Phase-supported Ligand Competitive Assay

We investigated the influence of desthiobiotin, biocytin, lipoic acid, and lysine on the solid phasesupported ligand competitive assay for biotin. Figure 7 shows that desthiobiotin (cross reactivity, $108 \%$ ) and biocytin (94\%) influenced the assay, but that lipoic acid and lysine did not. The cross-reactivity was independent of the blocking procedures (data not shown). Desthiobiotin [dethiobiotin, 6(5-methyl-2-oxo-imidazolidin-4-yl)-hexanoic acid] is an intermediate in the microbiological synthesis of biotin (cis-hexahydro-2-oxo-1H-thieno[3,4d]imidazole-4-pentanoic acid). $\left.{ }^{15}\right)$ Biocytin $(\varepsilon-N-$

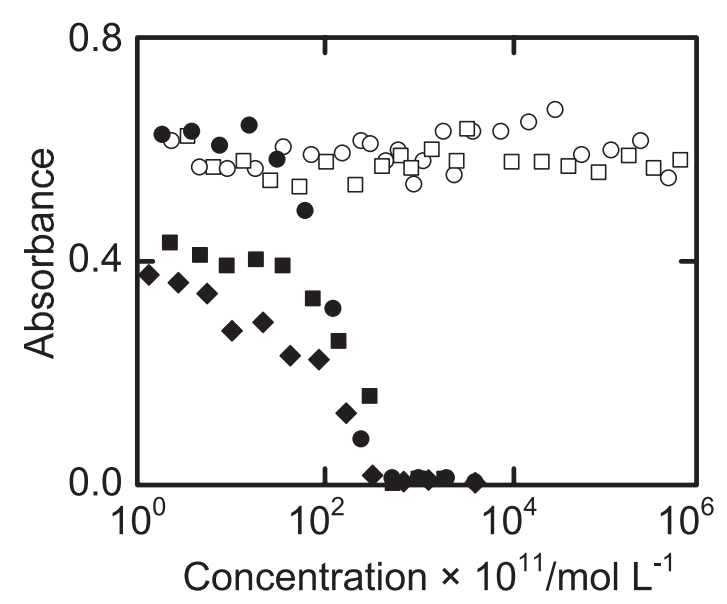

Fig. 7. Influence of Desthiobiotin ( $\bullet$ ), Biocytin ( $\bullet$ ), Lipoic Acid (○), and Lysine ( $\square$ ) on the Solid Phase-supported Ligand Competitive Assay for Biotin $(\bullet)$

The microplate wells were immobilized with B-BSA in BSA/PBS-N. 
biotinyl-L-lysine) is a compound formed when biotin covalently bonds to lysine through an amide linkage. Lipoic acid (1,2-dithiolane-3-pentanoic acid) is an essential cofactor for many enzyme complexes, such as the pyruvate dehydrogenase complex, and its dithiolane ring has a valeric acid chain as the tetrahydrothiophene ring of biotin has the side chain.

\section{REFERENCES}

1) Wolf, B. and Heard, G. S. (1989) Disorders of biotin metabolism. In The metabloic basis of inherited disease, 6th ed. (Scriver, C. R., Beaudet, A. L., Sly, W. S. and Valle, D. Eds.), McGraw-Hill, New York, pp. 2083-2103.

2) Mock, D. M. (2001) Biotin. In Handbook of vitamins, 3rd ed. (Suttie, J. W., McCormick, D. B., Rucker, R. B. and Machlin, L. J. Eds.), CRC Press, New York, pp. 397-426.

3) Green, N. M. (1990) Avidin and streptavidin. Methods Enzymol., 184, 51-67.

4) Nordlund, H. R., Hytönen, V. P., Laitinen, O. H. and Kulomaa, M. S. (2005) Novel avidin-like protein from a root nodule symbiotic bacterium, Bradyrhizobium japonicum. J. Biol. Chem., 280, 1325013255.

5) Meslar, H. W., Camper, S. A. and White, H. B. III (1978) Biotin-binding protein from egg yolk. J. Biol. Chem., 253, 6979-6982.

6) Dakshinamurti, K. and Chauhan, J. (1990) Nonavidin biotin-binding proteins. Methods Enzymol., 184, 93-102.
7) Fukui, T. and Oizumi, J. (1993) Biotin binding immunoglobulin and its clincal significance. Journal of Japanese Society for Mass-screening, 3, 125-131 (in Japanese).

8) Muratsugu, M., Yazawa, A., Fujiwara, S., Nishida, S. and Fukui, T. (2008) Quantitation of biotinbinding immunoglobulins $\mathrm{G}, \mathrm{A}$. and $\mathrm{M}$ in human sera using $\mathrm{F}(\mathrm{ab})_{2}$ anti-human immunoglobulincoated microplates. Biol. Pharm. Bull., 31, 507-510.

9) Eisenberg, M. A., Prakash, O. and Hsiung, S.-C. (1982) Purification and properties of the biotin repressor. J. Biol. Chem., 257, 15167-15173.

10) Goss, N. H. and Wood, H. G. (1984) Formation of $N$-(biotinyl)lysine in biotin enzymes. Methods Enzymol., 107, 261-278.

11) Manaka, Y. and Watanabe, T. (1990) Determination of biotin in blood. Vitamins, 64, 307-312 (in Japanese).

12) Fukui, T., Iinuma, K., Oizumi, J. and Izumi, Y. (1994) Agar plate method using Lactobacillus plantarum for biotin determination in serum and urine. $J$. Nutr. Sci. Vitaminol. (Tokyo), 40, 491-498.

13) Yazawa, A., Fukuoka, K., Honda, H., Fukui, T. and Muratsugu, M. (2006) Biotin-protein ratios and stability of biotinylated immunoglobulins as standards for the quantitation of biotin-binding immunoglobulins. Biol. Pharm. Bull., 29, 1480-1482.

14) Yazawa, A., Takeda, R. and Muratsugu, M. (2004) A simple computer program for the microplate reader. Journal of Rehabilition and Health Sciences, 2, 28 32 (in Japanese).

15) Izumi, Y. and Ogata, K. (1977) Some aspects of the microbial production of biotin. Adv. Appl. Microbiol., 22, 145-176. 